\title{
Effect of conjugated protein composed of porcine myofibril and Protaetia brevitarsis protein on protein functionality
}

\author{
T.-K. Kim ${ }^{1}$, H.-I. Yong1 ${ }^{1}$ J.-M. Sung ${ }^{1}$, H.W. Jang ${ }^{2}$ and Y.-S. Choi ${ }^{1 *}$ \\ ${ }^{1}$ Research Group of Food Processing, Korea Food Research Institute, Wanju 55365, Republic of Korea; ${ }^{2}$ Department of \\ Food Science and Biotechnology, Sungshin Women's University, Seoul 01133, Republic of Korea; kcys0517@kfri.re.kr
}

Received: 1 December 2020 / Accepted: 28 January 2021

(c) 2021 Wageningen Academic Publishers

OPEN ACCESS Cf) (1) () RESEARCH ARTICLE

\begin{abstract}
The replacement of conventional protein supply has been studied in the context of continuous population growth and the consequent environmental problems. Among protein substitutes, edible insects have gained relevance due to their high breeding efficiency. This study was conducted to estimate the effect of the partial replacement of porcine myofibril protein (pork protein; PP) with protein extracted from Protaetia brevitarsis (insect protein; IP) in protein-containing solutions and gels. The protein concentration was regulated at 30 and $1 \mathrm{mg} / \mathrm{ml}$ for gels and solutions, respectively, and the replacement percentages were increased by $20 \%$. Gels containing IP showed a lower viscosity and thermal stability; the texture and surface of the gels were negatively impacted as the replacement percentage increased. Therefore, heating is not an appropriate method to induce the gelation of IP containing solutions. However, the replacement of PP with IP increased the foam capacity and emulsion capacity in solutions. In conclusion, we show that the partial replacement of PP with IP positively impacts on protein solutions but impairs their gelation.
\end{abstract}

Keywords: edible insect, protein characteristics, functional properties, defatting

\section{Introduction}

Various alternative diet protein sources such as plant protein, cultured meat, and edible insects (non-livestockbased) have been studied to cope with the various environmental problems associated with livestock farming (Kumar et al., 2017; Post, 2012). Among these sources, edible insects have a lower feed conversion ratio than conventional livestock such as beef, pork, poultry, and lamb (Janssen et al., 2017). With this particular advantage, many studies have suggested that edible insects, particularly their protein extracts, can be used as food enhancers such as emulsifiers, foaming agents, and binders (Kim et al., 2019b; Mishyna et al., 2019; Yi et al., 2013). Among edible insects, Protaetia brevitarsis, Tenebrio molitor, and Allomyrina dichotoma are well-known; the first at the larva stage has the highest essential amino acid index, foaming properties, and emulsifying properties (Kim et al., 2020). In addition, it has been used as a therapeutic agent in East Asia because of its high antithrombotic and antioxidant properties (Ghosh et al., 2017; Lee et al., 2017). Therefore, P. brevitarsis, called white-spotted flower chafer beetle, can be used as meat alternatives to prepare processed meat products.

In the meat gelation process, myofibrillar protein in skeletal muscle is important, as it has good gelling properties with the heating condition and can be extracted easily in salting conditions (Macfarlane et al., 1977). When separated protein, that proteins called muscular protein are also composed in insect; of note, the saline solution can also extract insect proteins (IPs) (Kim et al., 2019a; Yi et al., 2016). Edible insects can either be used as additives or as direct meat substitution agents. On the one hand, some studies reported that the addition of edible insects to sausages or meat emulsions increased the quality of processed meat products (Kim et al., 2016; Park et al., 2017). On the other hand, the substitution of pork meat by mealworms did not affect the quality of a meat emulsion; in fact, an excessive substitute content decreased the quality of the meat emulsion (Choi et al., 2017). Furthermore, 
sausages consisting of only edible insects were of poor quality (Bessa et al., 2019). Therefore, optimisation of the processing conditions is required to potentiate the use of edible insects in meat products. Therefore, this study aimed to evaluate the effects of replacing the porcine myofibrillar protein (pork protein; PP) with proteins obtained from P. brevitarsis (IP).

\section{Materials and methods}

\section{Materials}

Freeze-dried $P$. brevitarsis on the third instar stage and pork meat were obtained from a conventional market. The chemical agents used in this study, except for those used in sodium dodecyl sulphate-polyacrylamide gel electrophoresis (SDS-PAGE), were obtained from SigmaAldrich Chemical Co. (St. Louis, MO, USA); the chemicals (tris-glycine electrophoresis, Coomassie Brilliant Blue R-250, and Precision Plus Protein ${ }^{\text {tw }}$ Dual Color Standard) and gels (12\% Mini-PROTEIN ${ }^{\circledR}$ TGXTM gels) for SDSPAGE were obtained from Bio-rad Lab., Inc. (Hercules, CA, USA).

\section{Protein extraction}

The excessive fat components from larvae were removed using n-hexane. Briefly, insect powder was mixed with n-hexane (5-fold) and stirred at ambient temperature for $1 \mathrm{~h}$ under a fume hood and repeated 5 times, and the defatted powder was left under the fume hood for another $12 \mathrm{~h}$ to remove the residual hexane. Subsequently, the defatted larvae and pork meat were dissolved in $0.58 \mathrm{M}$ saline solution $\left(0.49 \mathrm{M} \mathrm{NaCl}, 17.8 \mathrm{mM} \mathrm{Na}_{5} \mathrm{P}_{3} \mathrm{O}_{10}\right.$, and $\left.1 \mathrm{mM} \mathrm{NaN}_{3} ; \mathrm{pH} 8.3 ; 2{ }^{\circ} \mathrm{C}\right)$ at $1: 2(\mathrm{w} / \mathrm{v})$, and kept at $2{ }^{\circ} \mathrm{C}$ for $12 \mathrm{~h}$. The solutions were then centrifuged at $15,000 \times g$ for $30 \mathrm{~min}$ at $2{ }^{\circ} \mathrm{C}$, and the $\mathrm{pH}$ of the supernatants was adjusted to 5.4. The obtained residue was washed using distilled water, and the same processing was repeated three times to remove salts in extracts (Jiang et al., 2009). Finally, the salt-free proteins were freeze-dried, stored at $-20{ }^{\circ} \mathrm{C}$ and used within a week.

\section{Protein gel and solution preparation}

The IP and PP powder were dissolved in the saline solution used in protein extraction at 30 and $1 \mathrm{mg} / \mathrm{ml}$ to evaluate the gelation and solution properties, respectively. The solution was then homogenised at 4,000 rpm for $1 \mathrm{~min}$. Subsequently, the prepared PP and IP were mixed in a sequential replacing order, where the quantity of PP was replaced with IP following a $20 \%$ increment (100:0, $80: 20,60: 40,40: 60,80: 20,0: 100)$, and the end-products were labelled as IP0, IP20, IP40, IP60, IP80, and IP100, respectively. The contents were transferred to polyethylene bags and heated at $75^{\circ} \mathrm{C}$ for $30 \mathrm{~min}$, followed by cooling in an ice bath inducing thermal aggregation to obtain the heat-induced gels. Unheated samples were used as controls for differential scanning calorimetry (DSC) and apparent viscosity assays. The heated samples were also analysed to estimate gel solubility, texture profile analysis, and scanning electron microscopy (SEM). The foam and emulsion properties were estimated using the protein solutions. Furthermore, SDS-PAGE was performed to determine the molecular weight distribution of proteins in the preparations.

\section{Gel solubility}

Gel solubility was evaluated using 5 different solutions $(0.05$ $\mathrm{M} \mathrm{NaCl}$; SA, $0.6 \mathrm{M} \mathrm{NaCl}$; SB, $0.6 \mathrm{M} \mathrm{NaCl}+1.5 \mathrm{M}$ urea; SC, $0.6 \mathrm{M} \mathrm{NaCl}+8 \mathrm{M}$ urea; $\mathrm{SD}$, and $0.6 \mathrm{M} \mathrm{NaCl}+8 \mathrm{M}$ urea+0.5 M 2- $\beta$-mercaptoethanol; SE) (Lin et al., 2019). Two grams of each sample and $10 \mathrm{ml}$ of each solution were mixed at $300 \mathrm{rpm}$ at $2{ }^{\circ} \mathrm{C}$ for $3 \mathrm{~h}$ using a shaker (MaXshakeTM, Daihan Scientific, Seoul, Korea). The solutions were then centrifuged at $20,000 \times g$ for $15 \mathrm{~min}$, and the protein concentration of the supernatants was measured using the Bradford method (Kruger, 2009).

\section{Apparent viscosity}

The apparent viscosity of the samples was evaluated following the method reported by Alavi et al. (2020). Briefly, the samples were homogenised at a pre-shear rate of $50 \mathrm{~s}^{-1}$, and the viscosity of the samples was measured at a shear rate of $1-70 \mathrm{~s}^{-1}$ at $15^{\circ} \mathrm{C}$ using an HB-DV3T system with an SC4-29 spindle (Brookfield Engineering Inc., Stoughton, MA, USA). Data were converted to Pa"s using an analysis software (Brookfield Engineering Inc.).

\section{Scanning electron microscopy}

First, the samples were fixed using Karnovsky fixative at $4{ }^{\circ} \mathrm{C}$ for $12 \mathrm{~h}$ and washed 3 times using $0.05 \mathrm{M}$ sodium cacodylate buffer at room temperature for $10 \mathrm{~min}$, followed by a second fixation using osmium tetroxide in $0.1 \mathrm{M}$ sodium cacodylate buffer at $4{ }^{\circ} \mathrm{C}$ for $2 \mathrm{~h}$. Subsequently, the samples were washed with distilled water and then dehydrated with 30, 50, 70, 80, 90, and 99.8\% ethanol (Uengkimbuan et al., 2006). Micrographs of samples were taken using an S-2380N apparatus (Hitachi, Tokyo, Japan) after coating with a layer of gold (E-1010, Hitachi).

\section{Differential scanning calorimetry}

The thermal properties of the samples were estimated using a differential scanning calorimeter (PerkinElmer, Waltham, MA, USA). The empty aluminium pan as a reference and the sample pans containing $20 \mathrm{mg}$ of samples were used. The temperature range was $20-100{ }^{\circ} \mathrm{C}$ at a heating rate of $10{ }^{\circ} \mathrm{C} / \mathrm{min}$. The obtained data were analysed using Pyris 
(PerkinElmer) and the thermal properties of samples were estimated according to the method of Kazemi et al. (2011).

\section{Texture profile analysis}

The heat-induced gel was cut into $25-\mathrm{mm}$ diameter cylinders with a height of $2 \mathrm{~cm}$. A texture analyser (TAXT2i, Stable Micro Systems, Surrey, England) was used to estimate the texture. The detailed conditions were as follows: pretest speed $2 \mathrm{~mm} / \mathrm{s}$; test speed $2 \mathrm{~mm} / \mathrm{s}$; post-test speed $5 \mathrm{~mm} / \mathrm{s} ; 50 \%$ strain; force $10 \mathrm{~g}$ (Bourne et al., 1978).

\section{SDS-PAGE}

Twenty micrograms of samples and $4 \times$ sample buffer under non-reducing conditions were mixed and heated at $100^{\circ} \mathrm{C}$ for 5 min. Mini-PROTEIN ${ }^{\circledR}$ TGX $^{\mathrm{mm}}$ gels $(12 \%)$ and trisglycine electrophoresis buffer were used to run the samples at $80 \mathrm{~mA}$. Protein patterns were stained using Coomassie Brilliant Blue R-250, and the Precision Plus Protein ${ }^{\mathrm{mm}}$ Dual Color Standard was used as the molecular weight marker (Laemmli, 1970).

\section{Foaming capacity and foam stability}

Ten millilitres of each sample were loaded onto a conical tube and homogenised at 12,000 rpm for $2 \mathrm{~min}$. The foam volume was recorded and used to calculate foaming capacity (percentage; versus the initial volume); the decreased volumes at 2, 5, 10, 20, 30, and 60 min after homogenisation were used to calculate foam stability (percentage; versus the initial foam volume) (Mishyna et al., 2019).

\section{Emulsifying capacity and emulsion stability}

To $10 \mathrm{ml}$ of samples, $1 \mathrm{ml}$ of pure olive oil was added and homogenised at $18,000 \mathrm{rpm}$ for $2 \mathrm{~min}$. The difference between the emulsion layer volume and the initial volume was calculated as the percentage. After adding $50 \mu \mathrm{l}$ sample to $10 \mathrm{ml}$ of SDS solution, the absorbance at $500 \mathrm{~nm}$ was recorded at 5, 10, 20, 30, 60, 90, and 120 min and compared with the initial absorbance of the mixed samples (Pearce and Kinsella, 1978).

\section{Statistical analysis}

The one-way analysis of variance (ANOVA) with Duncan's multiple range test was conducted to evaluate significant differences among samples. A $P$-value of less than 0.05 was defined as statistically significant. The IBM SPSS statistics 20 software (IBM Corp., Armonk, NY, USA) was used for all the statistical analyses. The content of protein sources from pork and insects and the buffer type in the context of gel solubility were considered as fixed effects, while the other variants were considered as random effects.

\section{Results and discussion}

\section{Gel solubility}

The gelling properties can be determined via the analysis of ionic bonds, hydrogen bonds, hydrophobic bonds, and disulphide bonds (Zayas, 2012). In this study, five different solutions - SA, SB, SC, SD, and SE - were used to break ionic, hydrogen, hydrophobic, and disulphide bonds of gel (Lin et al., 2019). Solubility in SA represents the non-specific association, whereas the differential solubility in SA and SB, SB and SC, SC and SD, SD and SE were related with ionic bonds, hydrogen bonds, hydrophobic bonds, and disulphide bonds, respectively (Gomez-Guillen et al., 1997). All protein combinations in this study showed the highest value for hydrophobic bonds (Table 1), suggesting that hydrophobic bonds had a close relationship with the gelation of PP and IP (Lin et al., 2019). In addition, the replacement of IP with PP has increased the disulphide bonds in all combinations, which could be attributed to the changes in protein structure during the heat processing of the gels (Lin et al., 2019). These findings are consistent with Wang et al. (2017), who reported that heating reduced the ionic bonds and hydrogen bonds while increasing the disulphide and hydrophobic bonds in wheat gluten gelation (Wang et al., 2017).

Moreover, the non-specific association, ionic bonds, hydrogen bonds, hydrophobic bonds, and disulphide bonds were slightly increased with increasing IP content $(P<0.05$; Table 1). These results could be due to the interference of other components that could have reacted with the Bradford reagent, besides protein (Janssen et al., 2017). In insects, there are abundant amounts of acetyl glucosamine components such as chitin, and these components also have ionic bonds, hydrogen bonds, hydrophobic bonds, and disulphide bonds (Pillai et al., 2009). The chitin content in extracted $P$. brevitarsis protein powder has been reported to be $>3 \%$ (Kim et al., 2020). Although chitin is insoluble in distilled water, low molecular size chitin components of 25-75 kDa might be present within the supernatants since whole insects were used for protein extraction. Of note, these non-protein fractions could inhibit the enhancement of protein function (Kim et al., 2020). However, further investigations could help understand the exact effects of chitin on protein function.

\section{Apparent viscosity}

Generally, flow behaviour and gelling properties are closely related since the cross-linking strength between proteins affects them both (Zayas, 2012). Therefore, the apparent viscosity was measured to estimate the gelling properties. The apparent viscosity of the gels prepared from all combinations showed a decreasing tendency with increasing rotation time. It was noteworthy that the apparent viscosity of the gels containing IP0 and IP20 had a 
Table 1. Effect of partial replacement of porcine myofibril protein by Protaetia brevitarsis protein on gel solubility of heat-induced gel. ${ }^{1,2,3,4}$

\begin{tabular}{lllllll} 
& IP0 & IP20 & IP40 & IP60 & IP80 & IP100 \\
Nonspecific association $(\mathrm{mg} / \mathrm{ml})$ & $1.60 \pm 0.16^{\mathrm{Ec}}$ & $1.96 \pm 0.14^{\mathrm{Cc}}$ & $1.75 \pm 0.14^{\mathrm{Ec}}$ & $2.19 \pm 0.37^{\mathrm{Dc}}$ & $4.86 \pm 0.21^{\mathrm{Bd}}$ & $5.24 \pm 0.16^{\mathrm{Abc}}$ \\
lonic bonds $(\mathrm{mg} / \mathrm{ml})$ & $1.40 \pm 0.27^{\mathrm{Ec}}$ & $2.76 \pm 0.70^{\mathrm{Db}}$ & $2.14 \pm 0.13^{\mathrm{Dc}}$ & $3.67 \pm 0.70^{\mathrm{Cb}}$ & $5.41 \pm 0.20^{\mathrm{Ac}}$ & $5.06 \pm 0.23^{\mathrm{Bc}}$ \\
Hydrogen bonds $(\mathrm{mg} / \mathrm{ml})$ & $1.59 \pm 0.13^{\mathrm{Ec}}$ & $2.01 \pm 0.34^{\mathrm{Dc}}$ & $2.13 \pm 0.03^{\mathrm{Dc}}$ & $4.27 \pm 0.81^{\mathrm{Cb}}$ & $6.04 \pm 0.34^{\mathrm{Aab}}$ & $5.28 \pm 0.18^{\mathrm{Bbc}}$ \\
Hydrophobic bonds $(\mathrm{mg} / \mathrm{ml})$ & $2.70 \pm 0.13^{\mathrm{Da}}$ & $3.80 \pm 0.11^{\mathrm{Ca}}$ & $5.88 \pm 0.39^{\mathrm{Ba}}$ & $6.19 \pm 0.17^{\mathrm{Aa}}$ & $6.36 \pm 0.34^{\mathrm{Aa}}$ & $6.32 \pm 0.18^{\mathrm{Aa}}$ \\
Disulphide bonds $(\mathrm{mg} / \mathrm{ml})$ & $1.99 \pm 0.25^{\mathrm{Cb}}$ & $3.34 \pm 0.38^{\mathrm{Ba}}$ & $3.99 \pm 0.78^{\mathrm{Bb}}$ & $3.91 \pm 1.65^{\mathrm{Bb}}$ & $5.96 \pm 0.25^{\mathrm{Ab}}$ & $5.52 \pm 0.32^{\mathrm{Ab}}$ \\
\hline
\end{tabular}

\footnotetext{
${ }^{1}$ All values are mean \pm standard deviation of three replicates $(n=3)$.

${ }^{2} \mathrm{IP}$ and number meant insect protein and percentage of insect extracted powder in gel.

${ }^{3}$ Means within a row with different capital letters are significantly different $(P<0.05)$.

${ }^{4}$ Means within a column with different lower case letters are significantly different $(P<0.05)$.
}

similar decreasing tendency with increasing rotation time; however, it was decreased with increasing contents of IP in gels containing a higher proportion of IP powder ( $40 \%$ and over) (Figure 1). These results indicated that the apparent viscosities of the IP gels are lower than that of PP gel. Similar to our findings, a previous study has shown a lower apparent viscosity of a mealworm emulsion than that of an emulsion composed of pork meat (Choi et al., 2017), which could be explained by the lower water-binding capacity of insect versus pork meat (Kim et al., 2016). Furthermore, it has been shown that the higher hydrophobicity of proteins leads to a higher apparent viscosity; however, our results did not show this tendency, which could also be due to the non-protein fractions mentioned above, inhibiting the cross-linking between proteins.

\section{Scanning electron microscopy}

The cross-linking between the proteins was detected by SEM. IP0 had a compact and smooth surface appearance. However, the addition of IP turned the surface rough; moreover, the increase in IP content increased the porosity of the protein gel (Figure 2). Therefore, the high solubility of hydrophobic and disulphide bonds of IP may not be appropriate for gelation. Here we observed some linear and globular-shaped structures in the micrographs of gels, representing the long-chain Poly- $\mathrm{N}$-acetyl glucosamine molecules and proteins (Pillai et al., 2009; Uengkimbuan et al., 2006). Interestingly, the collapse of round structures was also observed with an increasing IP content indicating the inhibition of the thermal gelling reaction, and the decreased

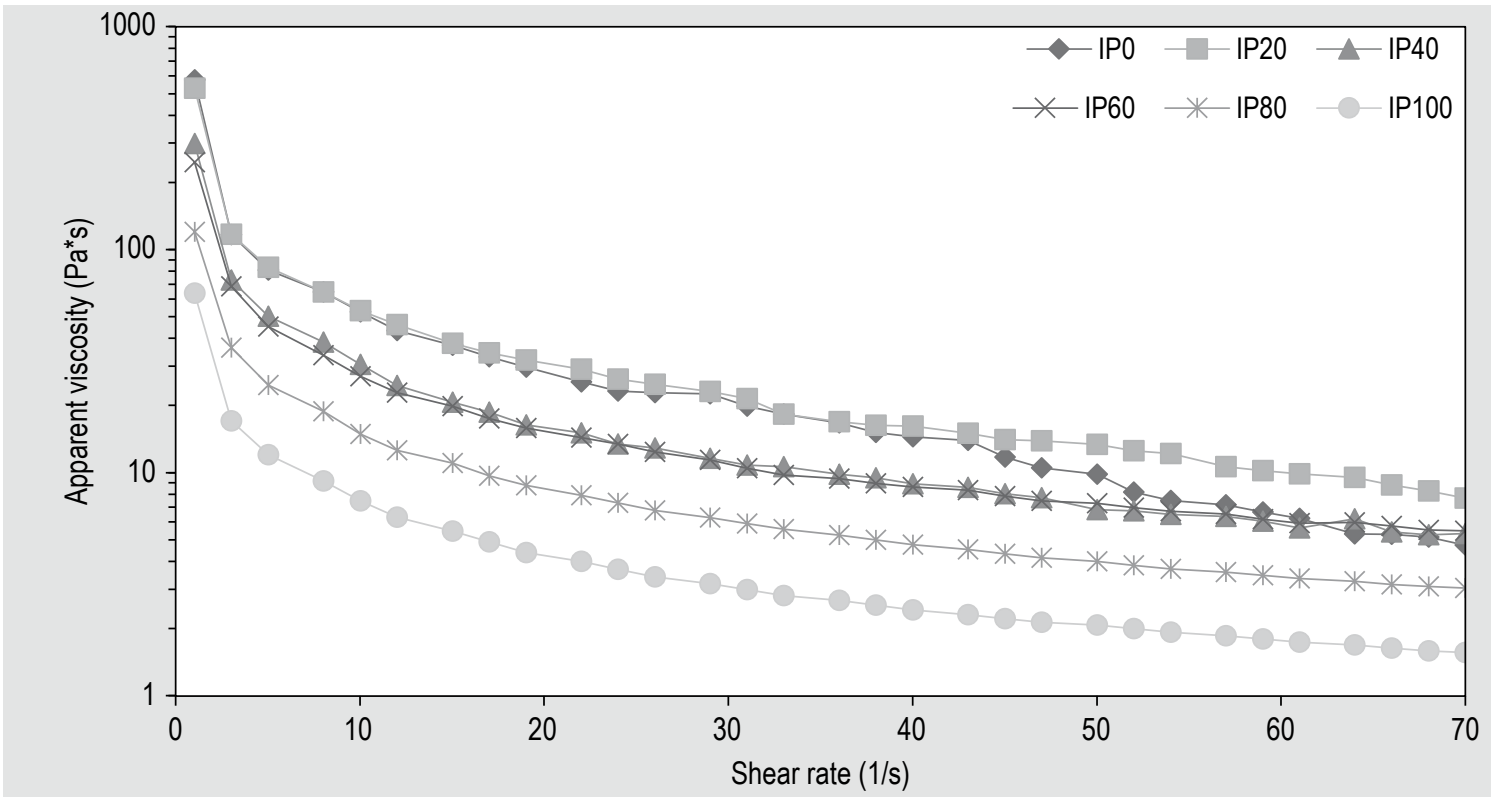

Figure 1. Effect of partial replacement of porcine myofibril protein by Protaetia brevitarsis protein on apparent viscosity of gel. IP and number meant insect protein and percentage of insect extracted powder in gel. 
gelling reaction could lead to poor gelling properties (Zayas, 2012). Taken together, these findings demonstrate that IPs might not be appropriate to form compact gel products.

\section{Differential scanning calorimetry}

DSC was used to estimate the thermal stability of proteins (Heussen et al., 2011) and deduce the effects of the heating process on protein denaturation and aggregation. The DSC analysis revealed a reducing effect of heating on all the parameters used to measure the thermal stability, including the onset temperature, peak temperature, end temperature, and change in enthalpy $(\Delta \mathrm{H})$ (Table 2). It has been shown that partial protein unfolding, the formation of new bonds between proteins, and the protein hydration proceed during thermal processing; protein thermal stability depends on protein hydration and the hydrophilic and hydrophobic reaction residue (Parniakov et al., 2018). Moreover, the variation in the above-mentioned thermal properties may depend on the type of protein (Quinn et al., 1980). In the present study, despite the high value of hydrophobic bonds, the IPs had a poor flow behaviour (Figure 1) and showed collapsed micrographs (Figure 2), which could explain the low thermal stability of IP-based gels. In addition, the reduced thermal stability of the IP-based gels could also be attributed to the low cross-linking power of IP. Furthermore, the peak temperature (denaturation temperature) was the highest in IP0, IP20, IP40, and IP $60(P<0.05)$, and the onset temperatures of IP0, IP20, and IP40 were not significantly different $(P>0.05)$. These results suggest that PP can increase the denaturation temperature and thermal stability in the context of gelation. However, the $\Delta \mathrm{H}$ of IP40 was lower than that of IP0 and IP20 $(P<0.05)$. This decreased $\Delta \mathrm{H}$ value could be related to protein unfolding and the interaction between the proteins (Parniakov et al., 2018). In addition, the increase in gel solubility and decrease in thermal properties could be attributed to the chitin content in edible insects (Kim et al., 2020). However, the thermal stability of chitin is very high, and it does not degrade at over $300{ }^{\circ} \mathrm{C}$ (Guinesi and Cavalheiro, 2006); therefore, the poor gel properties of the IP-based gels in this study could probably be due to some other components in IP whose structure was degraded at $75^{\circ} \mathrm{C}$.

\section{Texture profile analysis}

During thermal gelation, the denaturation of the components determines gel formation and the textural properties of the gel (Zayas, 2012). The hardness of the gel decreased rapidly with the replacement by IP (Table 3), consequently decreasing the gumminess and chewiness. Although the springiness was not different among treatments except for IP100, the other parameters were lower in gels containing IP than in gels containing 100\% PP. Importantly, these results align with those obtained in other studies, in the context of the substitution of meat by proteins extracted from the

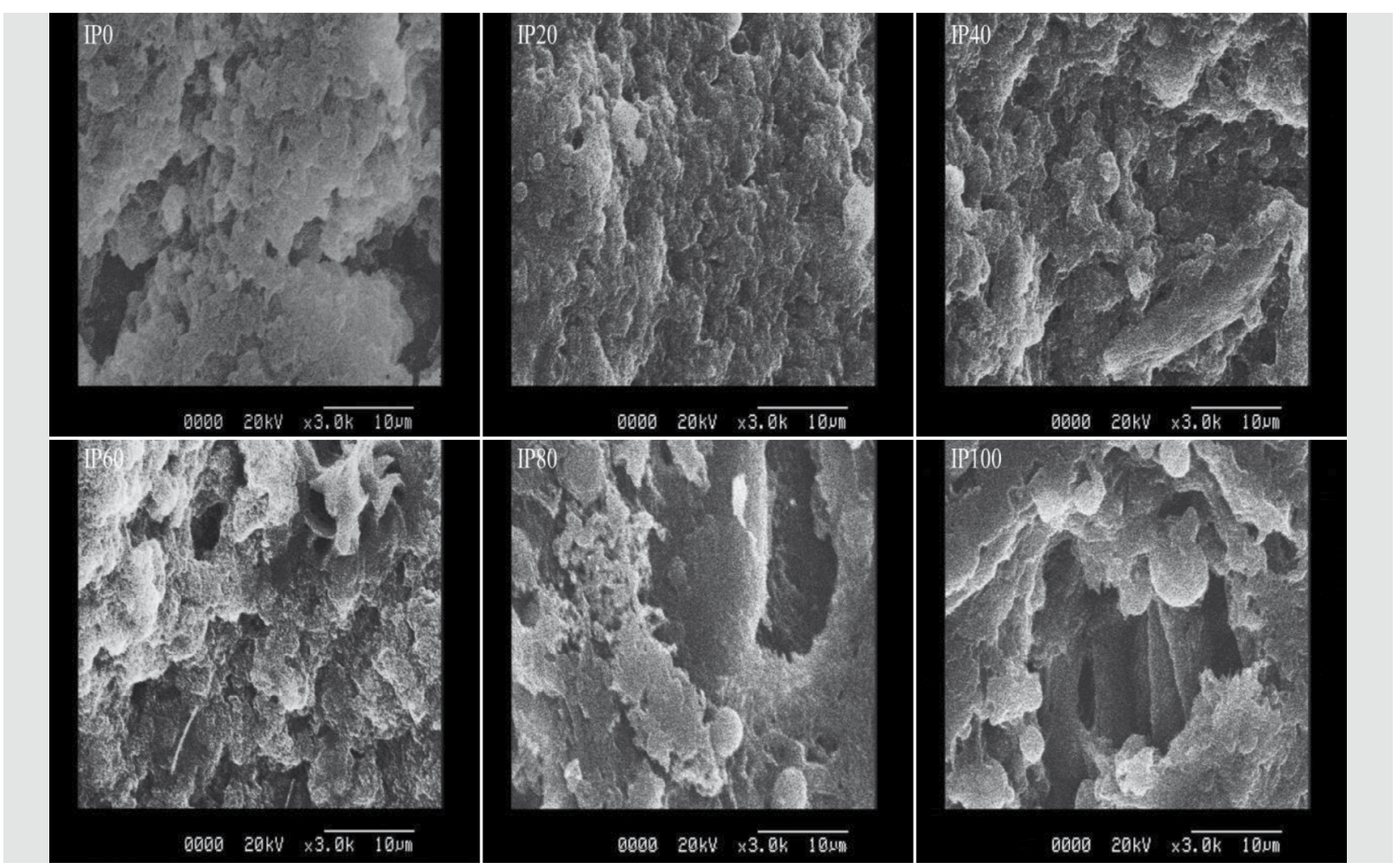

Figure 2. Effect of partial replacement of porcine myofibril protein by Protaetia brevitarsis protein on scanning electrical microscope of gel. IP and number meant insect protein and percentage of insect extracted powder in gel. 
Table 2. Effect of partial replacement of porcine myofibril protein by Protaetia brevitarsis protein on thermal properties of gel. ${ }^{1,2,3}$

\begin{tabular}{|c|c|c|c|c|c|c|}
\hline & IPO & IP20 & IP40 & IP60 & IP80 & IP100 \\
\hline Onset temperature $\left({ }^{\circ} \mathrm{C}\right)$ & $57.87 \pm 1.32^{\mathrm{a}}$ & $56.98 \pm 1.55^{\mathrm{a}}$ & $57.59 \pm 1.50^{\mathrm{a}}$ & $51.13 \pm 0.55^{b}$ & $46.46 \pm 0.80^{c}$ & $44.97 \pm 0.68^{c}$ \\
\hline Peak temperature $\left({ }^{\circ} \mathrm{C}\right)$ & $68.52 \pm 0.27^{a}$ & $68.54 \pm 0.14^{a}$ & $70.18 \pm 0.77^{a}$ & $68.14 \pm 0.48^{a}$ & $56.90 \pm 1.85^{b}$ & $54.78 \pm 2.42^{b}$ \\
\hline End temperature $\left({ }^{\circ} \mathrm{C}\right)$ & $79.76 \pm 2.19^{a}$ & $77.29 \pm 1.72^{\mathrm{ab}}$ & $77.32 \pm 1.28^{\mathrm{ab}}$ & $76.00 \pm 0.80^{\mathrm{ab}}$ & $73.61 \pm 2.68^{b}$ & $62.82 \pm 2.14^{c}$ \\
\hline Delta $\mathrm{H}(\mathrm{J} / \mathrm{g})$ & $1.64 \pm 0.05^{\mathrm{a}}$ & $1.35 \pm 0.29^{a}$ & $0.77 \pm 0.39^{b}$ & $0.75 \pm 0.06^{b}$ & $0.43 \pm 0.08^{b c}$ & $0.17 \pm 0.06^{c}$ \\
\hline
\end{tabular}

larvae of other insect species, such as mealworms and black soldier flies (Bessa et al., 2019; Choi et al., 2017). These studies showed that the poor cross-linking properties of edible IP might rapidly decrease the quality of meat proteins in the context of meat products.

As Line et al. (2019) reported, the higher the hydrophobicity of the gels, the higher is their strength (Lin et al., 2019). However, despite the increased hydrophobic and disulphide bonds imparted by the substitution by IP, the gel strength was decreased in this study. As observed by DSC, IP reduced the $\Delta \mathrm{H}$ value, which indicated lower unfolding of IP via heat-treatment than PP. Therefore, it was speculated that the lower unfolding rate, together with the non-protein fraction with high thermal stability, probably could have led to increased gel solubility. Furthermore, these non-protein fractions might inhibit protein-protein interactions or protein-water interactions, impair gel formation, and negatively impact the textural properties (Zayas, 2012).

\section{SDS-PAGE}

The molecular weight of proteins determines their functional properties; higher molecular weight proteins promote a stronger gel network (Wang and Damodaran,
1990). As shown in Figure 3, the bands between 25 and $50 \mathrm{kDa}$ and above $100 \mathrm{kDa}$ were weaker with an increase in the percentage of IP in the protein gels, while the bands between 50 and $75 \mathrm{kDa}$ were strong. Furthermore, widely spread but faint bands $(<15 \mathrm{kDa})$ were more intense, which was further increased with an increase in IP content. These results suggest that the molecular weight of IP is widely distributed. Pork meat consists of typical proteins such as myosin, actin, and sarcoplasmic components, whereas insect extracts may contain various components such as haemolymph proteins, enzymes, chitin, and various saltsoluble molecules (Yi et al., 2013, 2016). The observed protein between 14 and $32 \mathrm{kDa}$ could be an insect cuticle protein containing chitin; the increase in band intensity could, therefore, be explained by an increase in chitin content with an increasing IP content (Yi et al., 2013). Although proteins with low molecular weights may be irrelevant in the context of gel formation, they may contribute to the enhancement of protein functionality in solution at low protein concentration (Zayas, 2012). In fact, the hydrophobicity and protein concentration may have a critical impact on the foam and emulsion properties of protein solutions because excessive cross-linking was shown to interrupt the formation of stable foam and emulsion states (Baeza et al., 2004; Zayas, 2012).

Table 3. Effect of partial replacement of porcine myofibril protein by Protaetia brevitarsis protein on textural properties of gel. ${ }^{1,2,3}$

\begin{tabular}{|c|c|c|c|c|c|c|}
\hline & IPO & IP20 & IP40 & IP60 & IP80 & IP100 \\
\hline Hardness (kg) & $5.63 \pm 0.21^{a}$ & $0.39 \pm 0.12^{b}$ & $0.33 \pm 0.01^{b c}$ & $0.08 \pm 0.02^{c}$ & $0.08 \pm 0.01^{c}$ & $0.07 \pm 0.03^{c}$ \\
\hline Springiness & $0.99 \pm 0.02^{\mathrm{a}}$ & $0.94 \pm 0.04^{a}$ & $0.94 \pm 0.04^{a}$ & $0.89 \pm 0.04^{a}$ & $0.93 \pm 0.01^{\mathrm{a}}$ & $0.63 \pm 0.18^{b}$ \\
\hline Cohesiveness & $0.85 \pm 0.07^{a}$ & $0.59 \pm 0.01^{b}$ & $0.50 \pm 0.01 \mathrm{bc}$ & $0.48 \pm 0.04^{\mathrm{bcd}}$ & $0.43 \pm 0.08^{\mathrm{cd}}$ & $0.37 \pm 0.01^{d}$ \\
\hline Gumminess (kg) & $4.82 \pm 0.58^{a}$ & $0.19 \pm 0.05^{b}$ & $0.12 \pm 0.01^{b}$ & $0.04 \pm 0.01^{b}$ & $0.04 \pm 0.01^{b}$ & $0.03 \pm 0.02^{b}$ \\
\hline Chewiness (kg) & $4.76 \pm 0.65^{a}$ & $0.18 \pm 0.05^{b}$ & $0.12 \pm 0.01^{b}$ & $0.04 \pm 0.01^{b}$ & $0.04 \pm 0.01^{b}$ & $0.02 \pm 0.02^{b}$ \\
\hline
\end{tabular}




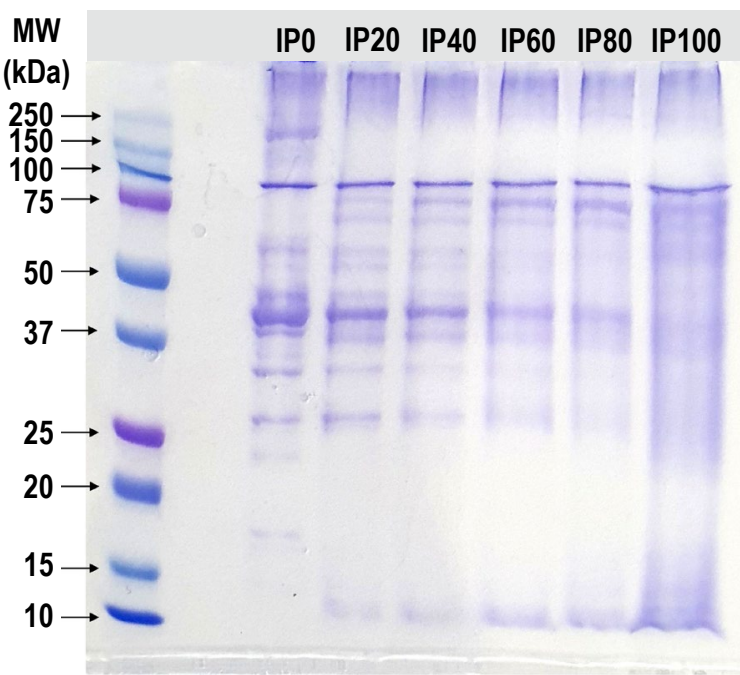

Figure 3. Effect of partial replacement of porcine myofibril protein by Protaetia brevitarsis protein on sodium dodecyl sulphate-polyacrylamide gel electrophoresis (SDS-PAGE) of solution. IP and number meant insect protein and percentage of insect extracted powder in solution.

\section{Foaming capacity and foam stability}

The formation of foam is an important factor in the determination of the physicochemical properties of proteins. Foam formation may be affected by $\mathrm{pH}$, ionic strength, protein structure, and protein hydrophobicity (Zayas, 2012). IP0 had the lowest, and IP60, IP80, and IP100 the highest foaming capacity $(P<0.05$; Figure $4 \mathrm{~A})$. These results are probably due to the different structural characteristics of IP and PP. Because high surface viscosity decreases the molecular flexibility of interfacial film during foam formation, low viscous proteins have a higher capacity to foam with larger bubbles (Poole et al., 1984; Zayas, 2012). Furthermore, as shown in Figure 2, the linear structure was observed in gels containing IP. These unfolded structures have a higher hydrophobicity than folded proteins, affecting an interfacial film strength (Zayas, 2012). Therefore, the foaming capacity of the solution containing IP was increased with the increase in the replacement content. However, large-sized bubbles may have poor foam stability; large bubbles and high value in initial foam volume usually show a decreased thickness of the protein film at the interface (Zayas, 2012). It was observed that the foam of IP0 remained over $60 \%$ until $60 \mathrm{~min}$, but more than half of the foam collapsed after $60 \mathrm{~min}$ in other treatments (Figure 4B). Since the size of the proteins also affects the thickness of the foam film, the high content of PP in the solution might have a positive effect on foam stability instead of IP.

\section{Emulsifying capacity and emulsion stability}

When PP was substituted by IP, the emulsifying capacity of the mixed protein was increased (Figure 5A) with increasing IP content. IP80 and IP100 showed the highest $(P<0.05)$, whereas IP0, IP20, and IP40 showed the lowest emulsifying capacity $(P<0.05)$. Among the various factors that could affect emulsifying capacity, protein hydrophobicity is one of the most important factors proteins with high hydrophobicity usually correlate with an increased emulsifying capacity (Kim et al., 2019a). As shown in Table 1, the replacement of PP with IP increased the hydrophobic bonds. Furthermore, the flexibility of proteins is important, particularly while considering the dispersion of oil droplets in water (Zayas, 2012). Concerning emulsion stability, IP had a negative effect,
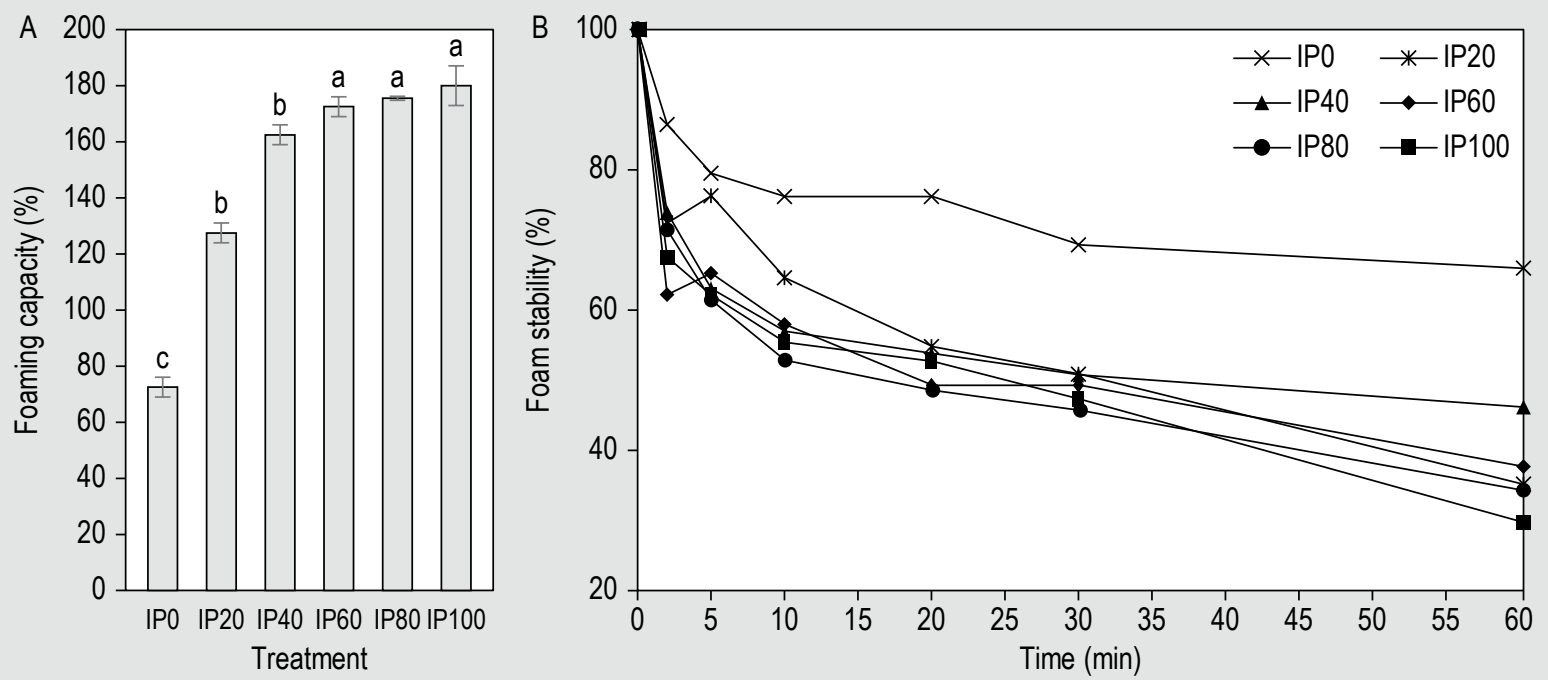

Figure 4. Effect of partial replacement of porcine myofibril protein by Protaetia brevitarsis protein on (A) foaming capacity and (B) foam stability of solution. Different letters on top of column means significant difference $(P<0.05)$. IP and number meant insect protein and percentage of insect extracted powder in solution. 
and the emulsion stability sharply decreased when IP and PP were mixed after 30 min (Figure 5B). Furthermore, when emulsions were generated using only one type of protein, the IP emulsion was more stable than the PP emulsion for $120 \mathrm{~min}$, indicating that the interfacial film was easily disrupted only when IP and PP were mixed. These results might be due to protein denaturation, as observed by DSC (Table 2). With the addition of IP, $\Delta \mathrm{H}$ was rapidly decreased, and this result indicated that myofibrillar protein could denature easily when mixed with IP. High denatured myosin in myofibrillar protein could induce the large size of cross-linked protein, and too large size of protein could induce the loss of molecular flexibility (Xia et al., 2010). Therefore, the low emulsion stability of the mixed protein solutions with highly denatured protein compared with pure protein solutions (IP0 and IP100) could be due to the loss of molecular flexibility that could have induced unstable emulsion formation (Zayas, 2012).

\section{Conclusion}

This study was conducted to estimate the effect of the partial replacement of PP with IP on the gelation and solution properties. Despite the higher amount of hydrophobic and disulphide bonds in the gels containing IP, they showed low viscosity, thermal stability, and a poor texture. However, the solution properties such as foaming and emulsion capacities increased when PP was replaced with IP. Overall, these findings demonstrate that the proteins extracted from P. brevitarsis were not sufficient to form a hard heat-induced gel; however, they are more suitable for use in a solution state with high physicochemical functionality.

\section{Acknowledgements}

This research was supported by the Main Research Program (E0211200-01) of the Korea Food Research Institute (KFRI) funded by the Ministry of Science and ICT (Republic of Korea). This research was also partially supported by the Livestock Industrialization Technology Development Program (321079-3) by the Ministry of Agriculture, Food and Rural Affairs (Republic of Korea).

\section{Conflict of interest}

The authors declare no conflict of interest.

\section{References}

Alavi, F., Emam-Djomeh, Z., Momen, S., Hosseini, E. and MoosaviMovahedi, A.A., 2020. Fabrication and characterization of acidinduced gels from thermally-aggregated egg white protein formed at alkaline condition. Food Hydrocolloids 99: 105337.

Baeza, R., Sanchez, C.C., Pilosof, A.M.R. and Patino, J.M.R.G., 2004. Interfacial and foaming properties of prolylenglycol alginates: effect of degree of esterification and molecular weight. Colloids and surfaces B: Biointerfaces 36: 139-145.

Bessa, L.W., Pieterse, E., Sigge, G., Hoffman, L.C. and Hoffman, L., 2019. An exploratory study into the use of black soldier fly (Hermetia illucens) larvae in the production of a Vienna-style sausage. Meat and Muscle Biology 3: 289-298.

Bourne, M.C., Kenny, J.F. and Barnard, J., 1978. Computer-assisted readout of data from texture profile analysis curves 1 . Journal of Texture Studies 9: 481-494.
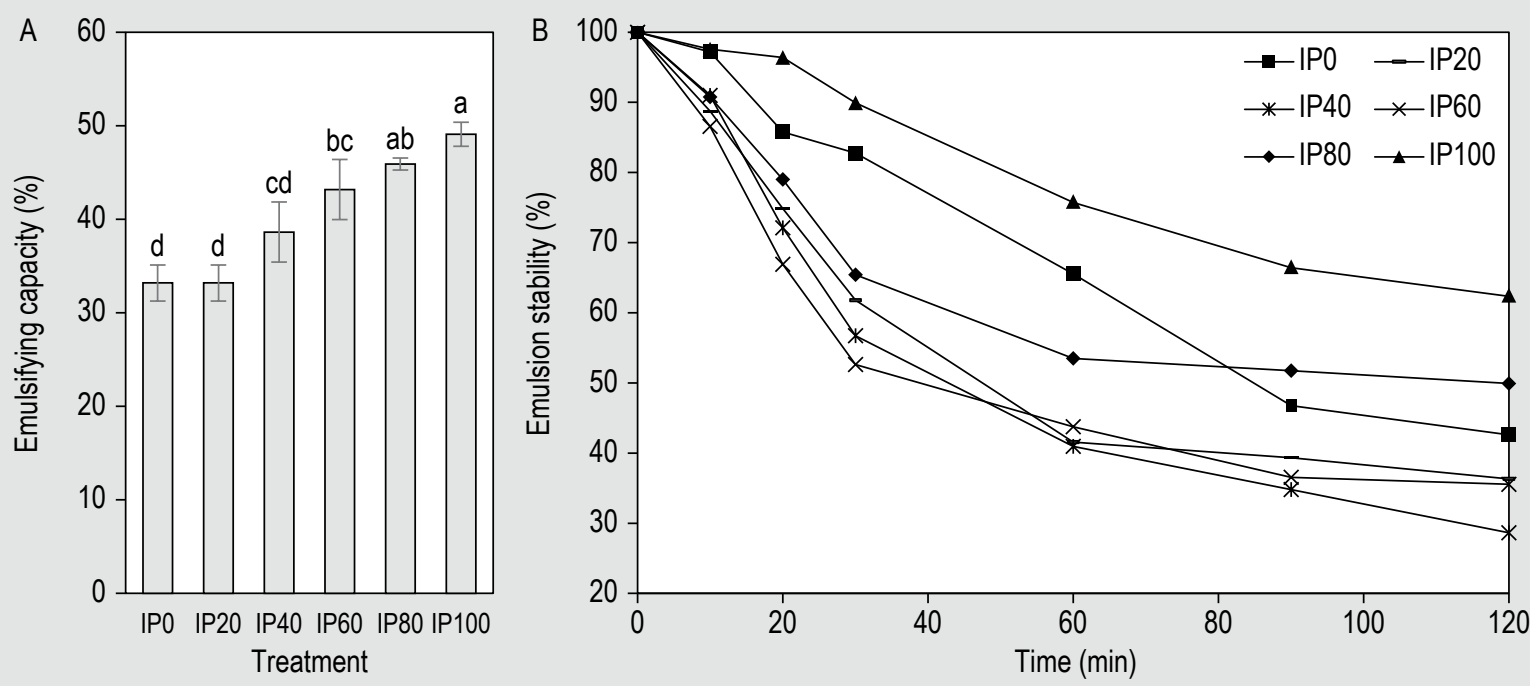

Figure 5. Effect of partial replacement of porcine myofibril protein by Protaetia brevitarsis protein on (A) emulsifying capacity and (B) emulsion stability of solution. Different letters on top of column means significant difference $(P<0.05)$. IP and number meant insect protein and percentage of insect extracted powder in solution. 
Choi, Y.S., Kim, T.K., Choi, H.D., Park, J.D., Sung, J.M., Jeon, K.H., Paik, H.D. and Kim, Y.B., 2017. Optimization of replacing pork meat with yellow worm (Tenebrio molitor L.) for Frankfurters. Korean Journal for Food Science of Animal Resources 37: 617-625.

Ghosh, S., Lee, S.M., Jung, C. and Meyer-Rochow, V.B., 2017. Nutritional composition of five commercial edible insects in South Korea. Journal of Asia-Pacific Entomology 20: 686-694.

Gomez-Guillen, M., Border1-as, A. and Montero, P., 1997. Chemical interactions of nonmuscle proteins in the network of sardine (Sardina pilchardus) muscle gels. LWT - Food Science and Technology 30: 602-608.

Guinesi, L.S. and Cavalheiro, É.T.G., 2006. The use of DSC curves to determine the acetylation degree of chitin/chitosan samples. Thermochimica Acta 444: 128-133.

Heussen, P., Ye, P., Menard, K. and Courtney, P., 2011. Practical food applications of differential scanning calorimetry (DSC). PerkinElmer, Inc., Shelton, CT, USA.

Janssen, R.H., Vincken, J.P., Van den Broek, L.A., Fogliano, V. and Lakemond, C.M., 2017. Nitrogen-to-protein conversion factors for three edible insects: Tenebrio molitor, Alphitobius diaperinus, and Hermetia illucens. Journal of Agricultural and Food Chemistry 65: 2275-2278.

Jiang, J., Chen, J. and Xiong, Y.L., 2009. Structural and emulsifying properties of soy protein isolate subjected to acid and alkaline $\mathrm{pH}$-shifting processes. Journal of Agricultural and Food Chemistry 57: 7576-7583.

Kazemi, S., Ngadi, M.O. and Gariépy, C., 2011. Protein denaturation in pork longissimus muscle of different quality groups. Food and Bioprocess Technology 4: 102-106.

Kim, H.W., Setyabrata, D., Lee, Y.J., Jones, O.G. and Kim, Y.H.B., 2016. Pre-treated mealworm larvae and silkworm pupae as a novel protein ingredient in emulsion sausages. Innovative Food Science \& Emerging Technologies 38: 116-123.

Kim, T.K., Yong, H.I., Chun, H.H., Lee, M.A., Kim, Y.B. and Choi, Y.S., 2020. Changes of amino acid composition and protein technical functionality of edible insects by extracting steps. Journal of AsiaPacific Entomology 23: 298-305.

Kim, T.K., Yong, H.I., Jeong, C.H., Han, S.G., Kim, Y.B., Paik, H.D. and Choi, Y.S., 2019a. Technical functional properties of water- and salt-soluble proteins extracted from edible insects. Food Science of Animal Resources 39: 643-654.

Kim, T.K., Yong, H.I., Kim, Y.B., Kim, H.W. and Choi, Y.S., 2019b. Edible insects as a protein source: a review of public perception, processing technology, and research trends. Food Science of Animal Resources 39: 521-540.

Kruger, N.J., 2009. The Bradford method for protein quantitation. In: Walker, J.M. (ed.) The protein protocols handbook. Springer Protocols Handbooks. Humana Press, Totowa, NJ, USA, pp. 17-24.

Kumar, P., Chatli, M., Mehta, N., Singh, P., Malav, O. and Verma, A.K., 2017. Meat analogues: health promising sustainable meat substitutes. Critical Reviews in Food Science and Nutrition 57: 923-932.

Laemmli, U., 1970. SDS-page Laemmli method. Nature 227: 680-685.

Lee, J., Lee, W., Kim, M.A., Hwang, J.S., Na, M. and Bae, J.S., 2017. Inhibition of platelet aggregation and thrombosis by indole alkaloids isolated from the edible insect Protaetia brevitarsis seulensis (Kolbe). Journal of Cellular and Molecular Medicine 21: 1217-1227.
Lin, D., Zhang, L., Li, R., Zheng, B., Rea, M.C. and Miao, S., 2019. Effect of plant protein mixtures on the microstructure and rheological properties of myofibrillar protein gel derived from red sea bream (Pagrosomus major). Food Hydrocolloids 96: 537-545.

Macfarlane, J., Schmidt, G. and Turner, R., 1977. Binding of meat pieces: a comparison of myosin, actomyosin and sarcoplasmic proteins as binding agents. Journal of Food Science 42: 1603-1605.

Mishyna, M., Martinez, J.I., Chen, J. and Benjamin, O., 2019. Extraction, characterization and functional properties of soluble proteins from edible grasshopper (Schistocerca gregaria) and honey bee (Apis mellifera). Food Research International 116: 697-706.

Park, Y.S., Choi, Y.S., Hwang, K.E., Kim, T.K., Lee, C.W., Shin, D.M. and Han, S.G., 2017. Physicochemical properties of meat batter added with edible silkworm pupae (Bombyx mori) and transglutaminase. Korean Journal for Food Science of Animal Resources 37: 351-359.

Parniakov, O., Bals, O., Barba, F.J., Mykhailyk, V., Lebovka, N. and Vorobiev, E., 2018. Application of differential scanning calorimetry to estimate quality and nutritional properties of food products. Critical Reviews in Food Science and Nutrition 58: 362-385.

Pearce, K.N. and Kinsella, J.E., 1978. Emulsifying properties of proteins: evaluation of a turbidimetric technique. Journal of Agricultural and Food Chemistry 26: 716-723.

Pillai, C.K.S., Paul, W. and Sharma, C.P., 2009. Chitin and chitosan polymers: chemistry, solubility and fiber formation. Progress in Polymer Science 34: 641-678.

Poole, S., West, S.I. and Walters, C.L., 1984. Protein-protein interactions: their importance in the foaming of heterogeneous protein systems. Journal of the Science of Food and Agriculture 35: 701-711.

Post, M.J., 2012. Cultured meat from stem cells: challenges and prospects. Meat Science 92: 297-301.

Quinn, J., Raymond, D. and Harwalkar, V., 1980. Differential scanning calorimetry of meat proteins as affected by processing treatment. Journal of Food Science 45: 1146-1149.

Uengkimbuan, N., Soponronnarit, S., Prachayawarakorn, S. and Nathkaranakule, A., 2006. A comparative study of pork drying using superheated steam and hot air. Drying Technology 24: 1665-1672.

Wang, C.H. and Damodaran, S., 1990. Thermal gelation of globular proteins: weight-average molecular weight dependence of gel strength. Journal of Agricultural and Food Chemistry 38: 11571164.

Wang, K.Q., Luo, S.Z., Zhong, X.Y., Cai, J., Jiang, S.T. and Zheng, Z., 2017. Changes in chemical interactions and protein conformation during heat-induced wheat gluten gel formation. Food Chemistry 214: 393-399.

Xia, X., Kong, B., Xiong, Y. and Ren, Y., 2010. Decreased gelling and emulsifying properties of myofibrillar protein from repeatedly frozen-thawed porcine longissimus muscle are due to protein denaturation and susceptibility to aggregation. Meat Science 85: 481-486.

Yi, L., Lakemond, C.M., Sagis, L.M., Eisner-Schadler, V., Van Huis, A. and Van Boekel, M.A., 2013. Extraction and characterisation of protein fractions from five insect species. Food Chemistry 141: 3341-3348. 
Yi, L.Y., Van Boekel, M.A.J.S., Boeren, S. and Lakemond, C.M.M., 2016. Protein identification and in vitro digestion of fractions from Tenebrio molitor. European Food Research and Technology 242: 1285-1297.
Zayas, J.F., 2012. Functionality of proteins in food. Springer Science \& Business Media, Berlin, Germany. 